\title{
Melanochelys trijuga (Schweigger 1812) - Indian Black Turtle
}

\author{
INDRANEIL DAS ${ }^{1}$ AND S. BHUPATHY ${ }^{2}$ \\ ${ }^{1}$ Institute of Biodiversity and Environmental Conservation, \\ Universiti Malaysia Sarawak, 94300 Kota Samarahan, Sarawak, Malaysia [idas@ibec.unimas.my]; \\ ${ }^{2}$ Sálim Ali Centre for Ornithology and Natural History, \\ Anaikatty(PO),Coimbatore 641 108,Tamil Nadu, India [bhupathy.s@gmail.com]
}

Summary. - The Indian black turtle, Melanochelys trijuga (Family Geoemydidae), is a mediumsized (carapace length to $38.3 \mathrm{~cm}$ ), mainly still-water species from northern, northeastern, and peninsular India, Sri Lanka, Myanmar, Nepal, Bangladesh, Thailand, and possibly Pakistan. Six subspecies are currently recognized. The turtle has been introduced to some of the islands of the western Indian Ocean by seafarers. Omnivorous in dietary habits, the species takes aquatic plants in addition to invertebrates and carrion. Two to 16 elongated, brittle-shelled eggs are laid, with eggs and hatchlings showing considerable size variation. The species, although in no immediate danger in India, is exploited in unknown numbers for food, and population declines have been reported from Sri Lanka.

Distribution. - Bangladesh, China (?), India, Maldives, Myanmar, Nepal, Pakistan (?), Sri Lanka, Thailand. Widespread in northern and northeastern India with a second widespread disjunct range in southern peninsular India, including Sri Lanka. Also occurs in southern Nepal, Bangladesh, Myanmar, western Thailand, and possibly eastern Pakistan and southwestern China. Also found in the Maldives (probably introduced), and introduced to Diego Garcia and the Chagos Archipelago.

Synonymy. - Emys trijuga Schweigger 1812, Clemmys (Clemmys) trijuga, Melanochelys trijuga, Nicoria trijuga, Geoemyda trijuga, Emys belangeri Lesson 1831, Clemmys theobaldi Lydekker 1885, Bellia theobaldi, Clemmys hydraspica Lydekker 1885, Clemmys punjabiensis Lydekker 1885.

SuBSPECIES. - Six subspecies are currently recognized: 1) Melanochelys trijuga trijuga (Indian Black Turtle) (synonymy: Emys trijuga Schweigger 1812, Geoemyda trijuga trijuga, Emys trijuga madraspatana Anderson 1879, Geoemyda trijuga plumbea Annandale 1915) (distribution: peninsular India, excluding the west coast); 2) Melanochelys trijuga coronata (Cochin Black Turtle) (synonymy: Emys trijuga coronata Anderson 1879, Nicoria trijuga coronata, Geoemyda trijuga coronata) (distribution: the west coast and associated hills of peninsular India); 3) Melanochelys trijuga edeniana (Burmese Black Turtle) (synonymy: Melanochelys edeniana Theobald 1876, Nicoria trijuga edeniana, Geoemyda trijuga edeniana, Emys trijuga edeniana, Melanochelys edeniana edeniana, Emys trijuga burmana Anderson 1879, Geoemyda trijuga wiroti Reimann in Nutaphand 1979, Melanochelys trijuga wiroti, Melanochelys edeniana wiroti) (distribution: Myanmar); 4) Melanochelys trijuga indopeninsularis (Bengal Black Turtle) (synonymy: Geoemyda indopeninsularis Annandale 1913, Geoemyda trijuga indopeninsularis, Melanochelys edeniana indopeninsularis) (distribution: northern and eastern India, southern Nepal, and Bangladesh); 5) Melanochelys trijuga parkeri (Parker's Black Turtle) (synonymy: Melanochelys trijuga parkeri Deraniyagala 1939, Geoemyda trijuga parkeri) (distribution: northern Sri Lanka); and 6) Melanochelys trijuga thermalis (Sri Lanka Black Turtle) (synonymy: Emys thermalis Lesson 1830, Clemmys thermalis, Nicoria trijuga thermalis, Geoemyda trijuga thermalis, Emys sebae Gray 1831, Melanochelys sebae, Emys trijuga sebae) (distribution: southeastern India and southern Sri Lanka).

STATUS. - IUCN 2009 Red List: Near Threatened (LR/nt, assessed 2000); CITES: Not Listed.

Taxonomy. - Originally described as Emys trijuga from "Java" by Schweigger (1812), the type locality is now known to be in error. Testudo scabra Linnaeus 1758 had previously been thought to be an older name for trijuga (see Boulenger 1889; Wermuth and Mertens 1977; Iverson 1992), but the identity of the scabra holotype has now been confirmed as a Rhinoclemmys punctularia (Rhodin and Carr 2009).

The species was referred to Geoemyda by Smith (1931) and Wermuth and Mertens (1961) and to Nicoria by Bou- lenger (1889). McDowell (1964) removed it to the genus Melanochelys, and placed it in the Geoemyda complex of batagurines. Synonyms include Emys belangeri Lesson 1831, Emystrijuga madraspatana Anderson 1879, Clemmys theobaldi Lydekker 1885, and Geoemyda trijuga plumbea Annandale 1915. There is considerable literature on the species under the name Geoemyda trijuga. The relationship of Melanochelys trijuga to other members of the Geoemydidae remains poorly resolved (Spinks et al. 2004). 


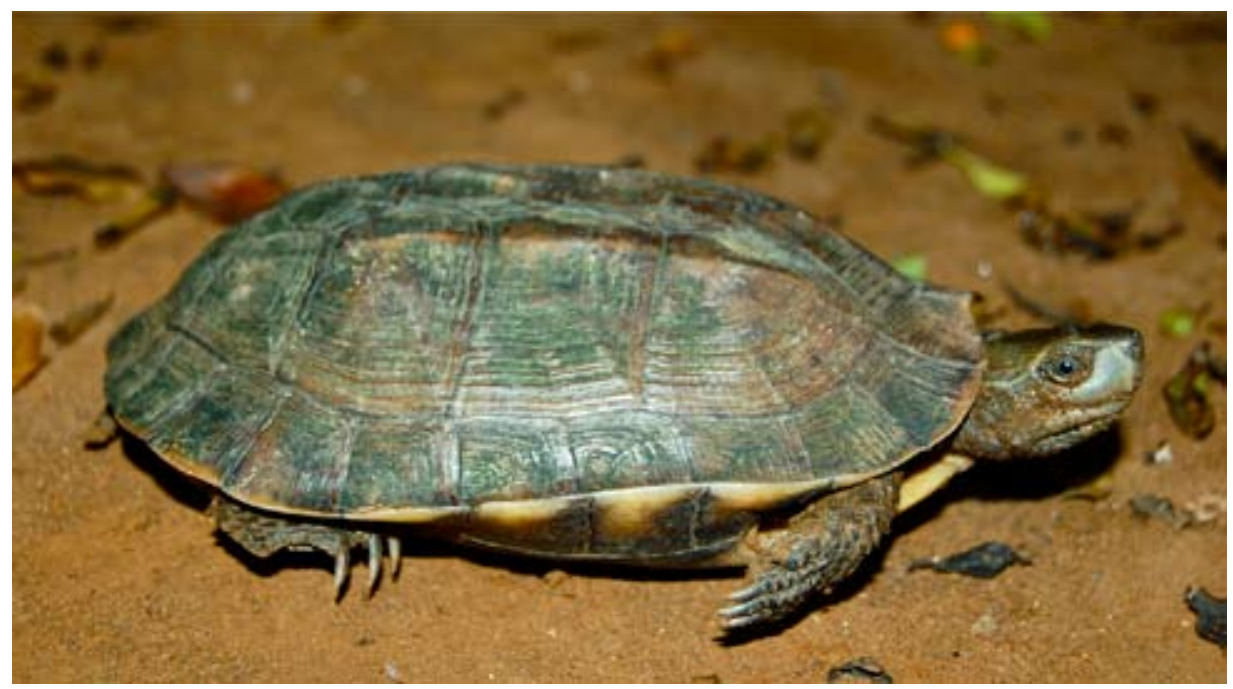

Figure 1. Melanochelys trijuga trijuga from Anaikatti Hills, Coimbatore, Western Ghats, Tamil Nadu, India. Photo by S. Jayakumar.

Six subspecies are recognized based primarily on head pigmentation and body size. The subspecies plumbea described by Annandale (1915) is apparently based on trijugacoronata intergrades. Intergradient populations of the two subspecies have been reported to occur along the ranges of the Western Ghats (see Das and Pritchard 1990).

Fossils of $M$. trijuga are known from the Pleistocene of the Siwaliks of northern India and Pakistan. These fossils were described as Clemmys theobaldi Lydekker 1885, and also possibly as Bellia sivalensis Theobald, Clemmys

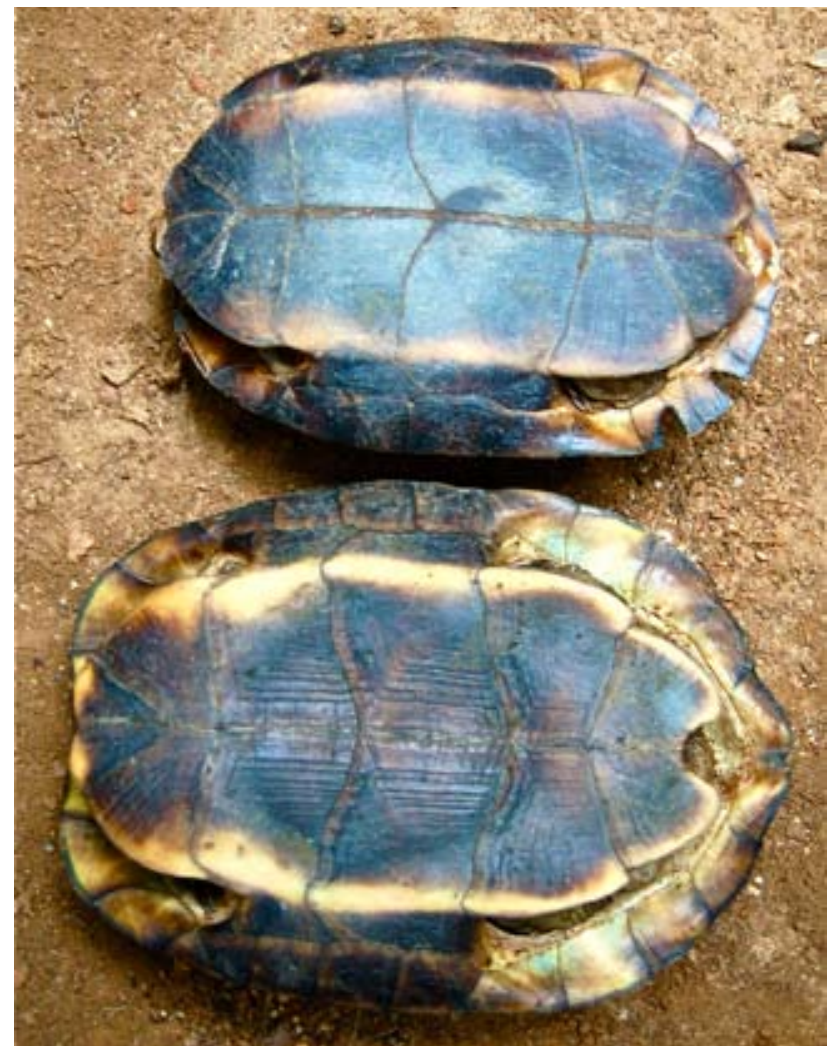

Figure 2. Melanochelys trijuga trijuga, adult female (top) and adult male (bottom) from Anaikatti Hills, Coimbatore, Western Ghats, Tamil Nadu, India. Photo by S. Jayakumar. hydraspica Lydekker, and Clemmys punjabiensis Lydekker (Lydekker 1885).

The name wiroti was made nomenclaturally available in a book by Nutaphand (1979), although the authority to the specific epithet was attributed to Reimann. Since Reimann's description of the taxon was never published, the name should be attributed to Reimann in Nutaphand 1979 (Obst 1983). The taxon was apparently founded on a juvenile purchased from a market on the Thailand-Myanmar border (see Thirakhupt and van Dijk 1994), and is currently
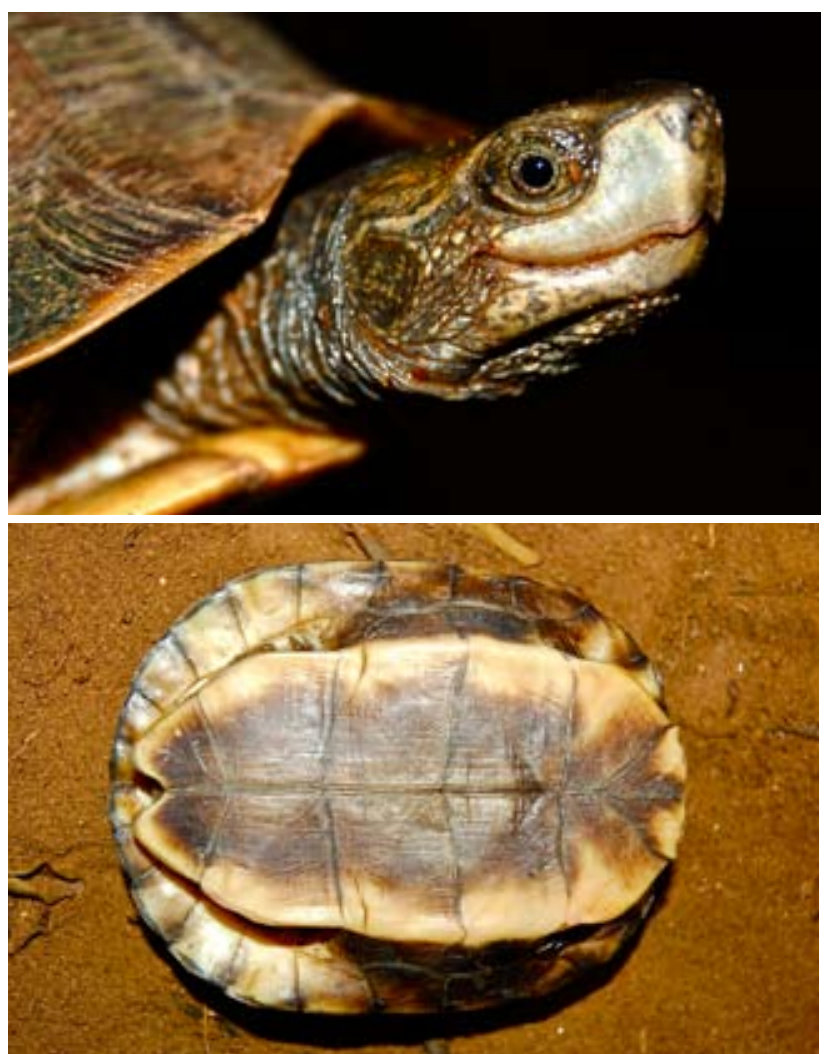

Figure 3. Melanochelys trijuga trijuga, adult female (top) and juvenile (bottom) from Anaikatti Hills, Coimbatore, Western Ghats, Tamil Nadu, India. Photos by S. Jayakumar. 


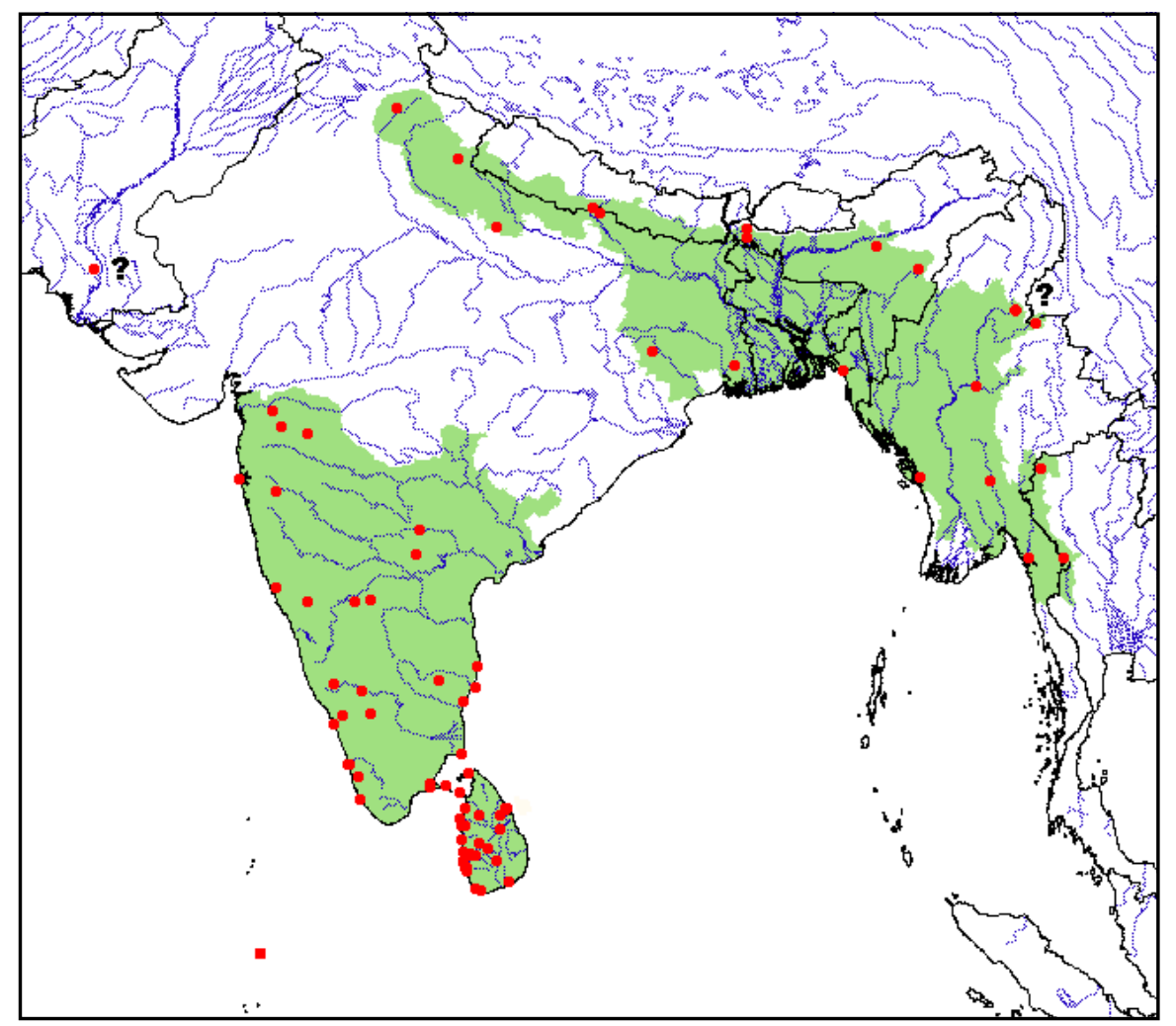

Figure 4. Distribution of Melanochelys trijuga in southern Asia. Red points = museum and literature occurrence records based on Iverson (1992) plus more recent and authors' data; green shading = projected distribution based on GIS-defined hydrologic unit compartments (HUCs) constructed around verified localities and then adding HUCs that connect known point localities in the same watershed or physiographic region, and similar habitats and elevations as verified HUCs (Buhlmann et al., in press), and adjusted based on authors' data. The population in the Maldives in the Indian Ocean (red square) is probably introduced. The four subspecies in the southern disjunct range are M.t.trijuga (India only), M.t. coronata (India only), M.t. parkeri (Sri Lanka only), and M.t. thermalis (India and Sri Lanka); the two subspecies in the northeastern disjunct range are M. t. indopeninsularis (India, Nepal, and Bangladesh) and M. $t$. edeniana (Myanmar and Thailand).
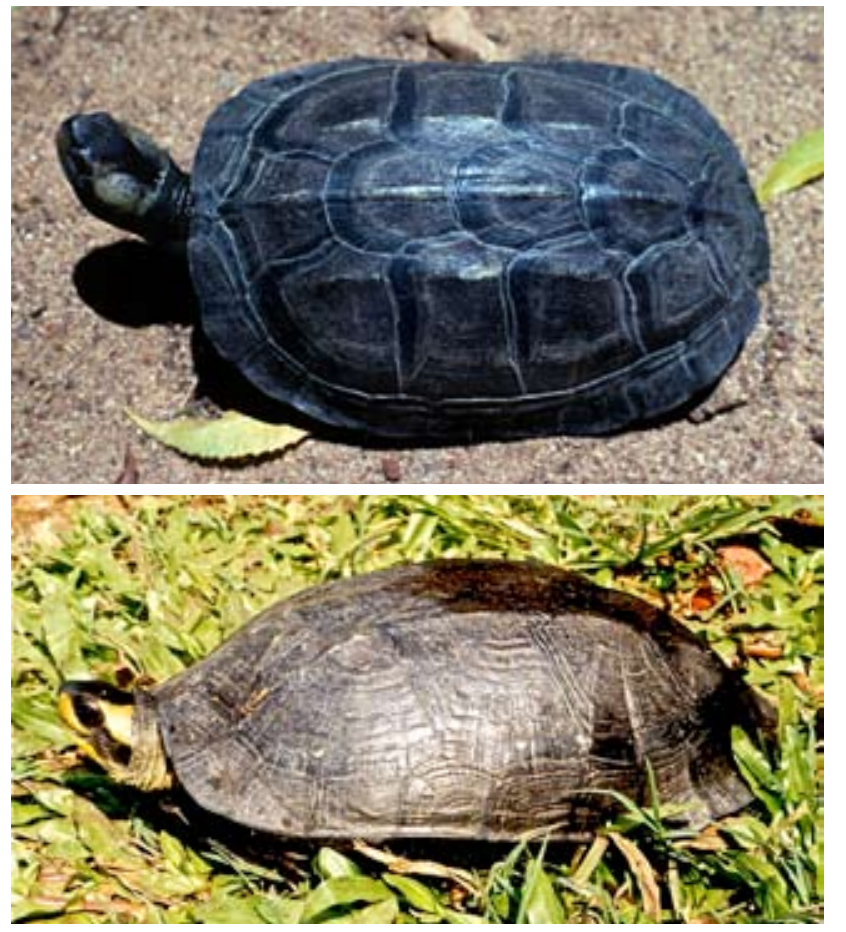

Figure 5. Melanochelys trijuga coronata, (top) adult from Kerala, Tamil Nadu, India, photo by Indraneil Das, (bottom) adult from Kumarakom, Kerala, India, photo by S. Bhupathy. a synonym of the subspecies name edeniana (see Fritz and Havaš 2007).

The species is phylogenetically most closely related to Melanochelys tricarinata and Vijayachelys silvatica (Iverson et al. 2007). No phylogeographic analysis has been carried out.

Description. - The carapace is elongated, relatively more elevated in adults and more depressed in juveniles, and tricarinate with feebly serrated marginals posteriorly. The nuchal scute is small and distinctly triangular. An interesting feature of the carapace is the octagonal second neural, a condition more frequently found in turtles showing megacephaly (see Pritchard 1988), and in this species may have been acquired from a comparatively more terrestrial ancestor. The plastron is about as long as the carapace, and truncated anteriorly.

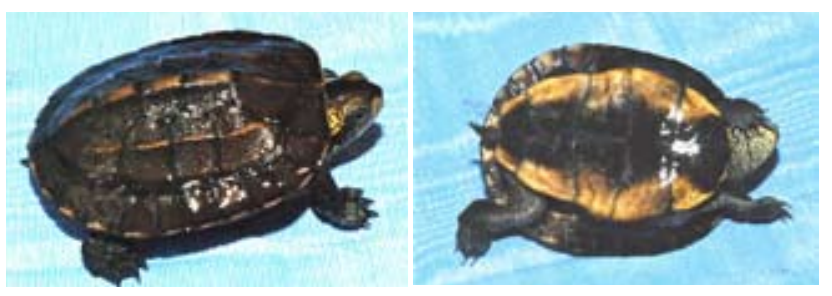

Figure 6. Melanochelys trijuga coronata, hatchling without data, photos by Hans-Dieter Philippen. 

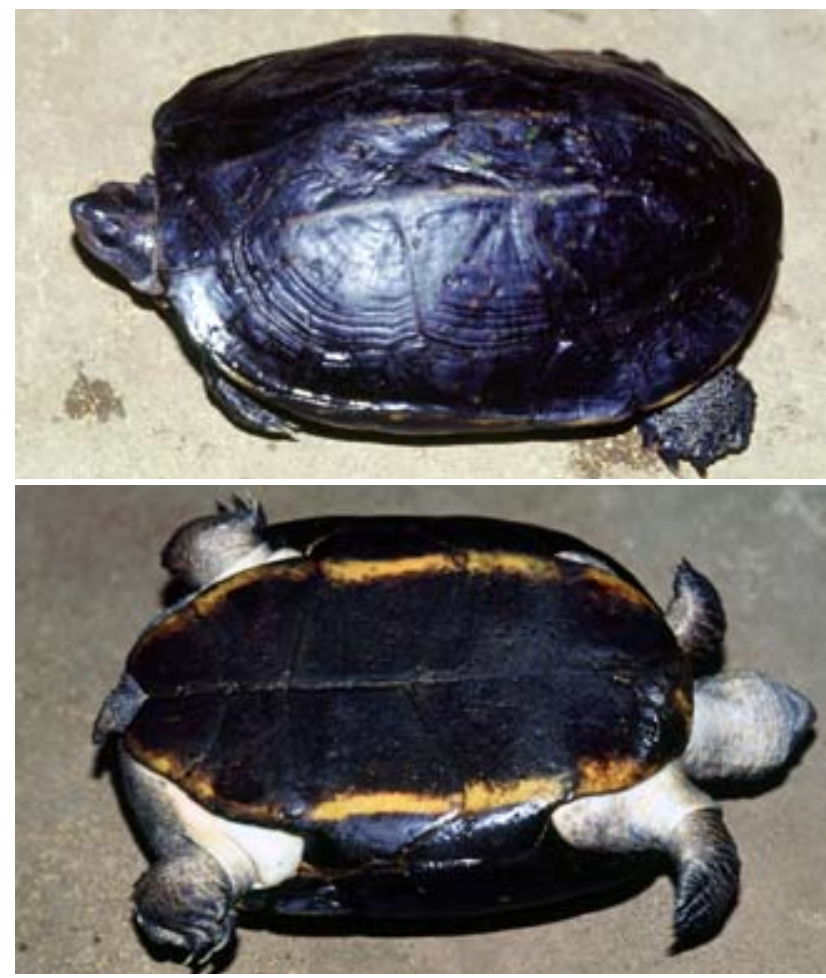

Figure 7. Melanochelys trijuga edeniana from Myanmar. Photos by Indraneil Das.

The head is moderate in size, with a short snout, which is shorter than the diameter of the eye. The upper jaw is notched; the ventral aspect of the jugal is narrow and separated from the pterygoid by the maxilla. The toes are fully webbed. The carapace is typically brown, whereas the plastron is usually brown with a lighter rim. The limbs can be gray, brown, or blackish. The nominotypical subspecies has pale yellow reticulations on the head, especially on the temporal region. The recognized subspecies are defined by differences in size and coloration.

Melanochelys trijuga trijuga has a straight carapace length (CL) up to $25.0 \mathrm{~cm}$, and the head has pale yellow reticulations, especially on the temples.

Melanochelys trijuga coronata has a CL up to $26.0 \mathrm{~cm}$, and a yellow head with a gray-black diamond-shaped mark on the forehead. The plastron is completely unpatterned black in adults, but not in juveniles.

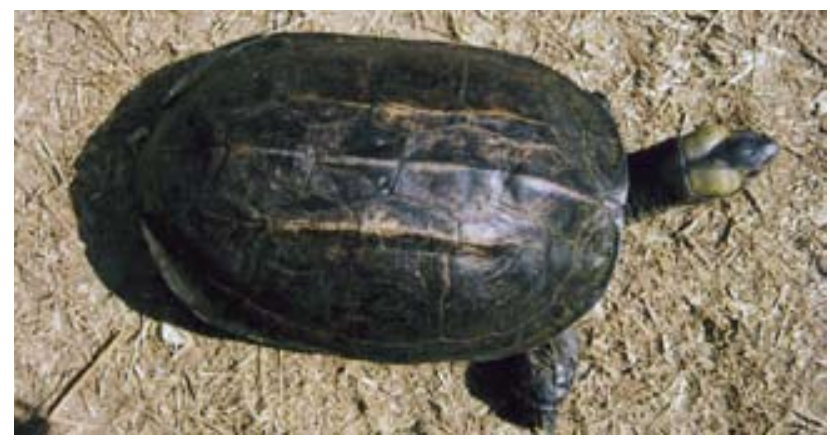

Figure 9. Melanochelys trijuga indopeninsularis from Rupa Lake, Pokhara, Nepal. Photo by Bhaba Amatya.

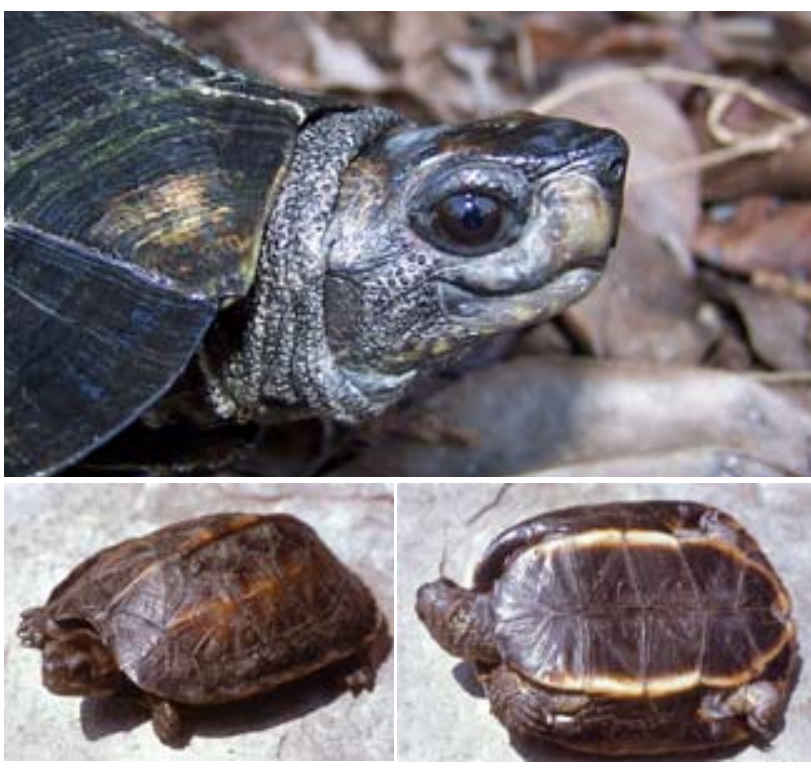

Figure 8. Melanochelys trijuga edeniana, (top) adult female from Myanmar, photo by Cris Hagen; (bottom) juvenile from the market in Ruili, Yunnan, China, photos by Gerald Kuchling.

Melanochelys trijuga edeniana has a CL up to $28.0 \mathrm{~cm}$, and the head is uniform gray or brown, or with indistinct yellow reticulations that may be absent in older individuals.

Melanochelys trijuga indopeninsularis has a CL up to $34.2 \mathrm{~cm}$, and the head is olive-brown with a long, spearshaped mark on the forehead. In large individuals, the lighter plastral rim disappears.

Melanochelys trijuga parkeri is the largest subspecies, with a CLup to $38.3 \mathrm{~cm}$, and the head is uniform olive-brown or finely spotted with orange.

Melanochelys trijuga thermalis has a CL up to $22.9 \mathrm{~cm}$, and the head is gray-black, and spotted or blotched with red, orange, or pink.

Intergrade populations (M.t. trijuga x coronata) have been found along the hill ranges of the southern Western Ghats of India (Das and Pritchard 1990). Thirty-two M.t. trijuga collected from the Anaikatti region in Tamil Nadu had mean curved CL, curved carapace width, plastron length, and mass of $170.2,139.7,132.8 \mathrm{~mm}$, and $514 \mathrm{~g}$, respectively. Mean values for 34 M.t. coronata collected from Kumarakom near the coastal town of Kerala were 184.5, 155.5, $144.1 \mathrm{~mm}$, and $746.2 \mathrm{~g}$, respectively (Mukherjee et al. 2006). The latter
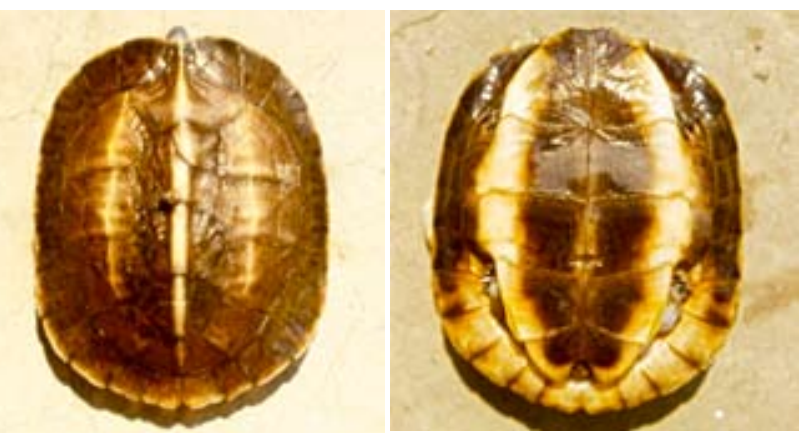

Figure 10. Juvenile Melanochelys trijuga indopeninsularis from Chitwan National Park, Nepal. Photos by Anders G.J. Rhodin. 


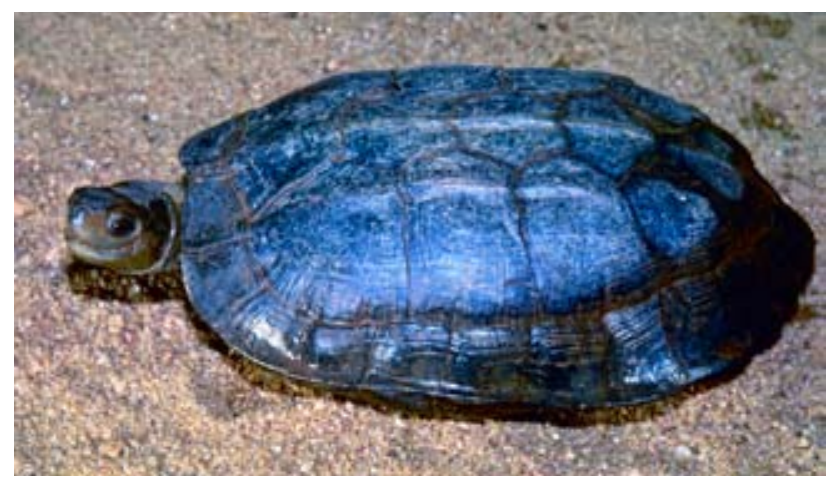

Figure 11. Melanochelys trijuga parkeri from Sri Lanka. Photo by Indraneil Das.

study reported that in both subspecies, males were larger and heavier than females and the populations had femalebiased sex ratios. Adult males possess concave plastra and comparatively thicker tails than females.

The karyotype is $2 \mathrm{n}=50$ (DeSmet 1978) or $2 \mathrm{n}=52$ (Carr and Bickham 1986; Sharma and Nakhasi 1981).

Distribution. - The species is distributed throughout much of India, except for a broad area of apparent absence from the arid plains of northern and northwestern peninsular India, causing the species to be split into two major disjunct ranges. The distribution in India includes the hill ranges of the Western Ghats, south of Gujarat (Daniel and Shull 1964), and the southeast coast, and then a separate disjunct distribution in northern and northeastern India (Das 1991; Pawar and Choudhury 2000).

Outside India, the distribution of the species includes Sri Lanka, the Maldives (where it was probably introduced), southern Nepal (Dinerstein et al. 1987; Mitchell and Rhodin 1996), Bangladesh (Das 1995, Rashid and Khan 2000), Myanmar, and extreme western Thailand from Tak Mae Hong Son Province (van Dijk and Thirakhupt 2000; Nabhitabhata et al. 2000). It has also been reported from some of the islands in the western Indian Ocean, including Diego Garcia and the Chagos Archipelago (Bourne 1886; Dutton 1980; Barnett and Emms 1997), but these records are no doubt based on introduced animals.

The subspecies of M.trijuga are generally distributed as follows: $M$.t. trijuga: peninsular India, excluding the west coast; $M$. t. coronata: the west coast and associated hills of peninsular India; M. t. edeniana: Myanmar and western Thailand; $M$. t. indopeninsularis: northern and eastern India, southern Nepal, and Bangladesh; M.t.parkeri: northern Sri Lanka; and M. t. thermalis: southeastern India and southern Sri Lanka.

The species may also possibly occur in extreme southwestern Yunnan, China, having been reported from the regional market in Ruili on the Myanmar border (Kuchling 1995). However, verified localities have only been recorded from adjacent regions of Myanmar.

Although known from Siwaliks Plio-Pleistocene deposits of northern and northwestern India and Pakistan (see Lydekker 1885), only a single live specimen of the species has been collected from Pakistan (AMNH 85594, from the
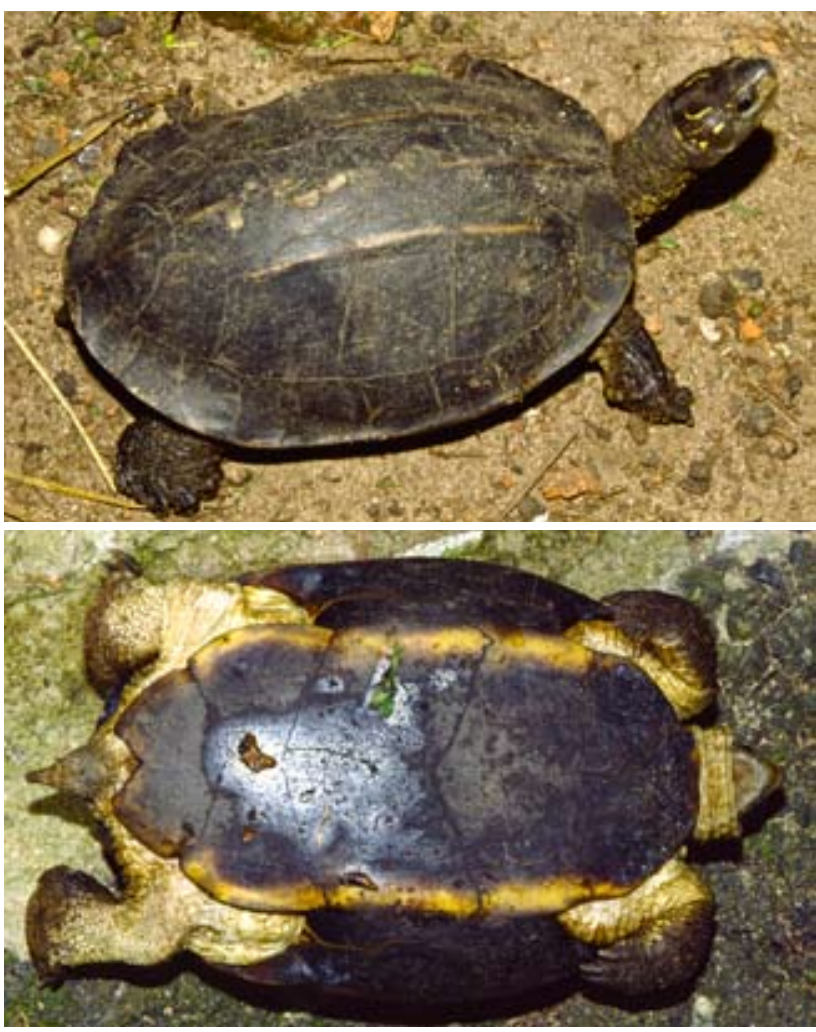

Figure 12. Melanochelys trijuga thermalis, adult female from near Bentota, Sri Lanka. Photos by Peter Paul van Dijk.

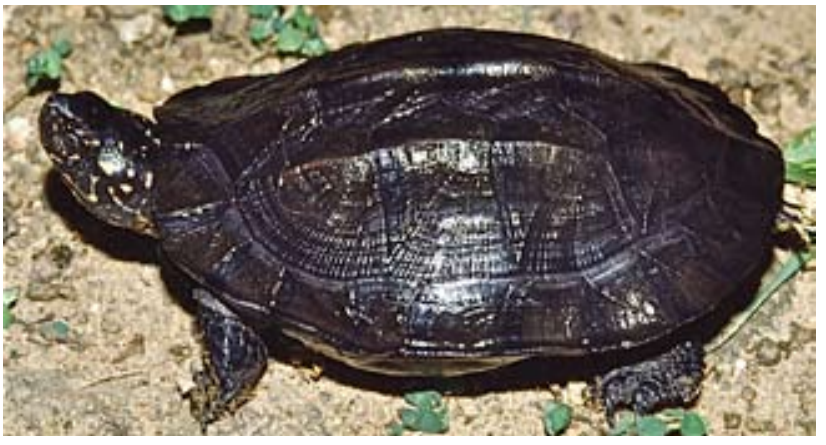

Figure 13. Melanochelys trijuga thermalis, juvenile from near Galle, Sri Lanka. Photo by Peter Paul van Dijk.
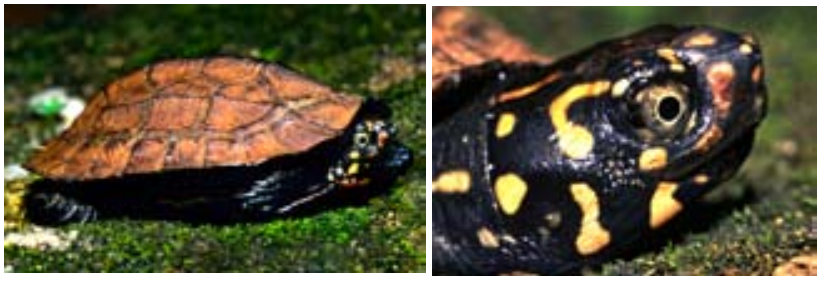

Figure 14. Juvenile Melanochelys trijuga thermalis from Gampola, Sri Lanka. Photos by Indraneil Das.

Indus River near Thatta, Sindh Province). Although this record is disregarded by most authorities, and the turtle has not been recorded in Pakistan since, the discovery of the species from adjacent Gujarat State in western India (Vyas and Patel 1990) and from the Siwaliks of Sirmaur District of Himachal Pradesh (Pendharkar and Jenner 1994) decreases the known hiatus in its western distribution. This suggests 
its possible presence in Pakistan, or at least its extirpation within the Holocene.

Arecord from Borneo (Gaffney 1979; based on FMNH 22054 ) is in error, as this species is not known from the fauna of that island (see Lim and Das 1999). The presence of live specimens of $M$. trijuga recently encountered in a collection in Kohima, Nagaland, India, reportedly collected from nearby forests, suggests a wider distribution in northeastern India than currently believed (Bhupathy, unpubl. data).

Habitat and Ecology. - Elevational distribution of the species ranges from sea level, in the Chennai region of southeastern India (Das, unpubl. data), up to ca. $800 \mathrm{~m}$, north of Pokhara in Nepal (Farkas and Csorba 1999), which along with its tolerance to human-modified ecosystems such as open areas of rice paddies, makes it a widespread turtle. In Dhikala, Uttar Pradesh, the species is found in man-made water holes, as well as in slow-moving streams within forested habitats (Frazier and Das 1994). In the Chennai area, the species occurs in ponds with water hyacinth (Eichhornia crassipes). Although it is essentially a species of stagnant waterbodies, it also occurs in running waterbodies, such as streams and rivers. During the dry season, it may be encountered a long distance from water. In Sri Lanka, juveniles have been found in the isolated sedge-covered side channels close to mountain streams (Das, unpubl. data), as well as marshes with brackish water influence (Porej 2001).

The species shows a crepuscular to nocturnal life style, with individuals seen foraging after dark along the edges of waterbodies in the area south of Madras, in southern India. In other parts of its range, after foraging the turtles may lie near the edge of the waterbodies spending the entire or most of the night outside water (Bhupathy, unpubl. data). As a defense response when picked up, turtles defecate copiously, in the manner of land tortoises, and also sometimes exude a vile-smelling fluid from the inguinal pores.

As an omnivore, both aquatic macrophytes and invertebrates are consumed. The species is also known to congregate in large numbers, sometimes comprising over a hundred turtles, on carcasses in forests, such as elephants poached for their tusks (R. Arumugam, pers. comm.). The stomachs of wild turtles taken in south India contained the remains of freshwater prawn, grass, water hyacinth, and fruits (Das 1991). A wild male from Himachal Pradesh, northern India, had remains of leaves, ants, and crustaceans in its scat (Pendharkar and Jenner 1994). In Sri Lanka, these turtles feed on garbage washed from drain mouths, in addition to fish trapped in kraals, fallen fruits, snails, insect larvae, and animal feces (Deraniyagala 1939). In Sri Lanka, the water monitor (Varanus salvator) is known to eat the turtle.

Ewert (1985) mentioned that the species copulates between August and October, ovulation lasting from September to January. Two to six clutches, comprising one to four, rarely five, eggs are laid in a year.Eggs are elongate and hard brittle-shelled. Hatchling M.t. thermalis measure 44.1 mm CL, and the average CL of five M.t.trijuga hatchlings was $44.0 \mathrm{~mm}$ (Ewert 1979).

Copulation takes place during the monsoons (July and August) in the Madras region of south India. The copulating pair floats on or near the surface of the water and males bite the nape and neck of the females during courtship.

The nominotypical subspecies is known to lay clutches of three to seven (mean 5.33) eggs, measuring $44.5 \times 26.8$ $\mathrm{mm}$ in average dimensions (Das 1991). Eggs are laid in January, February, and April, the beginning of the dry season. Hatchlings emerge in May and June, toward the middle of the dry season. Incubation periods for $21 \mathrm{eggs}$ at room temperature were 52-407 (mean 110.8) days.

Clutch size of $M$. $t$. thermalis ranges between four to five (mean 4.25) eggs, measuring $48.9 \times 27.6 \mathrm{~mm}$ in average dimensions. Eggs are laid in April and May (the middle of the dry season), hatching taking place during July, August, and October (wet season), after an incubation period of 76-149 (mean 107.6) days at room temperature (Das 1991).

Melanochelys $t$. indopeninsularis is known to produce clutches of up to 16 eggs in captivity.McCann(1934) reported nesting by this subspecies in the third week of October, when five eggs of mean dimensions 46 x $26 \mathrm{~mm}$ were laid by one turtle. Shyam Sundar (1984) found a nesting turtle of the same subspecies in the third week of October, in the Chennai area of southeastern India. The female utilized the left hind limb to dig, while the right hind limb pushed away the excavated earth. Nest-excavation lasted $30 \mathrm{~min}$, and seven eggs were laid at ca. 1 min intervals. Nest depth to the top-most egg was $100 \mathrm{~mm}$. A clutch of six eggs was laid by this subspecies in the fourth week of January, and hatched at the end of May, after an incubation period of 125 days at $29^{\circ} \mathrm{C}$ (Vijaya 1982). In Nepal, two clutches of three and six eggs, probably of the subspecies indopeninsularis, had average egg dimensions of $49.1 \times 27.3$ and 47.4 × 27.4 $\mathrm{mm}$, respectively (Dinerstein et al. 1987).

There are few records of nesting of the southwestern Indian subspecies, M. t. coronata. Vijaya (1982) noted that a female laid four eggs in the second week of January. Mean egg dimensions were $47 \times 27.5 \mathrm{~mm}$, and two hatchlings with CL of $41 \mathrm{~mm}$ emerged in the fourth week of May, after 105 days incubation at $29.5^{\circ} \mathrm{C}$.

Population Status. - Frazier and Das (1994) reported a large population in Dhikala, Corbett National Park, northern India, within a moist deciduous forest. In the Madras area of south India, low population densities within apparently suitable areas are attributed to exploitation and pollution. In many other localities in southern India, including the Western Ghats, this is often the most abundant species of turtle, frequently seen after the first rains. In the Vembanad Lake of Kerala, 34 individuals were collected by three personnel between 2000-2200 h during March 2004 (Bhupathy, unpubl. data). In Sri Lanka, populations are probably intact in the uplands and some of the lowland areas, where large numbers can be seen within protected areas, such as Pollanaruwa and Udawattakale. In the Maldives, where the species was probably introduced 
by sailors, it was reported common in the ponds of Hululé in the early 1930s (Deraniyagala 1956).

Threats to Survival. - Excavations at an archeological site at Gedige, Anuradhapura, Sri Lanka reveal that the species was consumed by early humans, between $800-500$ B.C. and 100-300 A.D. (Chandraratne 1997). Porej (2001) and Das and de Silva (2005) reported contemporary consumptive exploitation of the turtle from the island.

At present, the species appears to be in no immediate danger within India and Nepal; however, it is commercially exploited for food in northeastern India and subsistence hunting of the species by tribal groups is known in the Western Ghats of southwestern India as well as northeastern India (Das 1991; Pawar and Choudhury 2000). The species is extensively used by the local inhabitants of northern West Bengal State, especially around Gorumara National Park, as evidenced from the presence of large number of shells in cattle sheds of villages. Collection of this species is extensive in Kerala and the meat is sold in liquor shops. Preparations (meat fry) of about $100 \mathrm{~g}$ may cost about Indian Rupees 50 (= ca. US\$ 1) (Bhupathy, unpubl. data). One hatchling was offered for sale at Indian Rupee 40 in a pet shop in Trivandrum, Kerala (Choudhury and Bhupathy 1993), although the quantities in the pet trade remain unknown.

The turtle is threatened in parts of Sri Lanka, although abundant within protected areas. Its status in Myanmar and Bangladesh is unknown, and the species is suspected to be threatened by local exploitation. Its use as food in western Myanmar has been recorded by Platt et al. (2001).

In Nepal, fires set either accidentally, or intentionally during the dry season to promote growth of foliage during the wet season, is known to kill these turtles, as noted in Royal Bardia National Park (Mitchell and Rhodin 1996). These authors also recorded a trade in curio masks for tourists, made from shells of this species, in Kathmandu, Nepal.

Conservation Measures Taken. - Melanochelys trijuga is protected under the Fauna and Flora Protection (Amendment) in SriLanka 1972, which indicates that capture, killing and possession is prohibited. In Thailand, the turtle is listed in the Wild Animal Reservation and Protection Act B.E. 2535 of 1992. In Myanmar, it is protected under the Myanmar Wildlife Law (1994), as well as under Myanmar Fisheries Law (1993) (Maung and Ko Ko 2002). The species is listed in the Red Data Book of Nepal (Shah and Tiwari 2004). The species has been listed as Near Threatened on the IUCN Red List since 2000, but is not listed on the CITES Appendices.

As a result of its widespread distribution and relatively intact populations, $M$. trijuga probably occurs within most protected areas in its range. It has specifically been recorded from Corbett, Dudhwa, Gorumara, Manas, Mudumalai, Ngenpui, and Nongkhyllem Wildlife Sanctuaries and National Parks in India, Chitwan and Royal Bardia National Parks in Nepal, and Lahugala Kitulana, Wilpattu, and Yala National Parks in Sri Lanka.

Conservation Measures Proposed. - Assessment of numbers utilized in trade in India is recommended. Moreover, surveys of status and distribution within all the countries where the species occurs is advisable. In particular, surveys are needed in Myanmar, from where there are no data for the last century. A range-wide phylogeographic analysis would be helpful to elucidate relationships among the currently recognized subspecies.

Captive Husbandry. - A questionnaire survey in 120 Indian zoological parks and other captive breeding centers during 1991 revealed the presence of this species in seven facilities (Choudhury and Bhupathy 1993). The four subspecies that occur in India (trijuga, coronata, indopeninsularis, and thermalis) are maintained in ponds at the Madras Crocodile Bank Trust, where they feed on aquatic macrophytes and chopped fish. A large sand bank provides a resting place and substrate for egg-laying. A large number of trees provide shade. Stocking in high densities in glass-fronted aquariums is known to increase agonistic behavior, with turtles biting each other on the nape region. When maintained in captivity, they accumulate an unknown species of green filamentous algae on their neck and carapaces, which does not otherwise affect health or cause mortality.

Flower (1925) recorded one specimen that lived in captivity for 12 years and nine months, but longevity in the wild remain unknown.

Current Research. - B.K. Sharath of Mangalore University studied the ecology of the species in the central ranges of the Western Ghats, utilizing radiotelemetry. The trapping techniques used are described in Sharath and Hegde (2003). Long-term studies on behavior and breeding biology of the four Indian subspecies are being carried out at the Madras Crocodile Bank Trust, in southern India, including a study on temperature-dependent sex determination in the species.

Acknowledgments. - Supported by the Centre for Herpetology, Madras Crocodile Bank Trust, Universiti Malaysia Sarawak, and the Sálim Ali Centre for Ornithology and Natural History. We thank the late Chokalingam, J. Vijaya, and P.C.H. Pritchard, for companionship in the field, Chandini Menon for time spent candling eggs in the "Egg-Room", R. Arumugam for unpublished information on this species, Varad Giri for helping complete a citation, and Genevieve V.A. Gee and John B. Iverson for reviewing the manuscript.

\section{LITERATURE CITED}

ANDERSON,J.1879 [“1878”].Anatomical and Zoological Researches, Comprising an Account of the Zoological Results of the Two Expeditions to Western Yunnan in 1868 and 1875. London: Bernard Quaritch, Vol. I, 985 pp., Vol. II, plates.

Annandale, N. 1913. The tortoises of Chota Nagpur. Records of the Indian Museum 9(5):63-78.

AnNAndale, N. 1915. Notes on some Indian Chelonia. Records of the Indian Museum 11:189-195.

BARNETT, L.K. AND EMMS, C. 1997. Herpetological observations in the Chagos Archipelago, British Indian Ocean Territory. Bulletin of the British Herpetological Society 59:6-12.

Boulenger, G.A. 1889. Catalogue of the Chelonians, Rhynchocepha- 
lians, and Crocodilians in the BritishMuseum(Natural History). British Museum (Natural History), London, $311 \mathrm{pp.}$

Bourne, G.C. 1886. General observations on the fauna of Diego Garcia, Chagos Group. Proceedings of the Zoological Society of London 1886:331-334.

Buhlmann, K.A., Akre, T.S., Iverson, J.B., Karapatakis, D., MittermeIER,R.A.,GeORges,A.,Rhodin,A.G.J., vANDiJK,P.P., AND GiBBONS,J.W.In press.A global analysis of tortoise and freshwater turtle distributions with identification of priority conservation areas. Chelonian Conservation and Biology 8(2): in press.

CARR, J.L. AND BickHAM, J.W. 1986. Phylogenetic implications of karyotype variation in the Batagurinae (Testudines: Emydidae). Genetica 70:89-106.

Chandraratne, R.M.M. 1997. Some reptile bones from the Gedige Excavation in 1985, the citadel of Anuradhapura, Sri Lanka. Lyriocephalus 3(2):7-15.

Choudhury, B.C. And Bhupathy, S. 1993. Turtle Trade in India. World Wide Fund for Nature-India, New Delhi, 50 pp.

DANIEL, J.C. AND SHull, E.M. 1964. Alist of the reptiles and amphibians of the Surat Dangs, south Gujarat. Journal of the Bombay Natural History Society 60:737-743.

DAs, I. 1991. Colour Guide to the Turtles and Tortoises of the Indian Subcontinent. R \& A Publishing Limited, Portishead, 133 pp.

DAS,I. 1995. Turtles and Tortoises of India. Oxford University Press, Bombay, $176 \mathrm{pp}$.

DAS,I. AND DE SILVA,A.2005.APhotographic Guide to the Snakes and Other Reptiles of Sri Lanka. New Holland Publishers (UK), Ltd., London/Ralph Curtis Books, Sanibel Island, Florida, 144 pp.

DAS,I. AND PRITCHARD, P.C.H. 1990.Intergradation between Melanochelys trijuga trijuga and M.t. coronata (Testudines: Emydidae: Batagurinae). Asiatic Herpetological Research 3:52-53.

Deraniyagala, P.E.P. 1939. The Tetrapod Reptiles of Ceylon. Vol. 1. Testudinates and Crocodilians. Dulau and Co., London, 412 pp.

DeraniYagala, P.E.P. 1956. Zoological collecting at the Maldives in 1932. Spolia Zeylanica 28:7-15.

Desmet, W.H.O. 1978. The chromosomes of 11 species of Chelonia (Reptilia). Acta Zoologica Pathologica Antverpiensia 70:15-34.

Dinerstein, E., Zug, G.R., AND Mitchell, J.C. 1987. Notes on the biology of Melanochelys (Reptilia, Testudines, Emydidae) in the Terai of Nepal. Journal of the Bombay Natural History Society 84:687-688.

DutTon, R.A. 1980. The herpetofauna of the Chagos Archipelago. British Journal of Herpetology 6:133-134.

EwERT,M.A.1979.The embryo and the egg: development and natural history.In:Harless,M.and Morlock,H.(Eds.).Turtles:Perspectives and Research, Wiley Interscience, New York, pp: 333-416.

EwERT,M.A. 1985.Embryology of turtles.In: Gans,C.(Ed.).Biology of the Reptilia. Vol. 14. Development A. John Wiley and Sons, Inc., New York, pp. 75-267.

FARKAS, B. AND CSORBA, G. 1999. Notes on the distribution and maximum size of Melanochelys trijuga indopeninsularis in Nepal (Reptilia: Testudines: Bataguridae). Faunistische Abhandlungen Staatlisches Museum für Tierkunde Dresden 21(21):305-307.

FLOWER, S.S. 1925. Contributions to our knowledge of the duration of life in vertebrate animals. III. Reptiles. Proceedings of the Zoological Society of London 1925:911-981.

FraZiER, J.G. AND DAS, I. 1994. Some noteworthy records of Testudines from the Indian and Burmese Subregions. Hamadryad 19:47-66.

FritZ, U. AND HaVAš, P. 2007. Checklist of chelonians of the world. Vertebrate Zoology 57(2):139-368.

GAFFNEY, E.S. 1979. Comparative cranial morphology of recent and fossil tortoises. Bulletin of the American Museum of Natural
History 164:67-376.

Gray, J.E. 1831. Synopsis Reptilium; or Short Descriptions of the Species of Reptiles. Part I.-Cataphracta. Tortoises, Crocodiles, and Enaliosaurians. London: Treuttel, Wurz, and Co., 85 pp.

Iverson, J.B. 1992. A Revised Checklist with Distribution Maps of the Turtles of the World. Richmond, IN: Privately printed, $363 \mathrm{pp}$.

Iverson, J.B., Brown, R.M., AKre, T.S., NeAR, T.J., Le, M., ThOMSON, R.C., ANDSTARKEY,D.E. 2007.Insearch of the tree of life forturtles.In: Shaffer,H.B., FitzSimmons, N.N., Georges,A., and Rhodin,A.G.J. (Eds.). Defining Turtle Diversity: Proceedings of a Workshop on Genetics,Ethics, andTaxonomy of FreshwaterTurtles andTortoises. Chelonian Research Monographs No. 4, pp. 85-106.

KuCHLING, G. 1995. Turtles at a market in western Yunnan: possible range extensions for some southern Asiatic chelonians in China and Myanmar. Chelonian Conservation and Biology 1(3):223-226.

Lesson, R.P. 1830. Centurie Zoologique, ou Choix d'Animaux Rares, Nouveaux ou Imparfaitement Connus. Paris: F.G. Levrault, 235 pp.

LESSON,R.P.1831.Reptiles. In: Bélanger,C.(Ed.). Voyage aux IndesOrientales, par le Nord de l'Europe, les Provinces du Caucase, la Géorgie, l'Arménie et la Perse, suivi de Détails topographiques, statistiques et autres sur le Pégou, les Iles de Java, de Maurice et de Bourbon, sur le Cap de Bonne-Espérance et Sainte-Hélène, pendant les Années 1825, 1826, 1827, 1828 et 1829. Zoologie. Paris: A. Bertrand, pp. 289-336.

Lim, B.L. AND DAS, I. 1999. Turtles of Borneo and Peninsular Malaysia. Natural History Publications (Borneo), Sdn. Bhd., Kota Kinabalu, 151 pp.

Linnaeus, C. 1758. Systema Naturae per Regna Tria Naturae, Secundum Classes, Ordines, Genera, Species, cum Characteribus, Differentiis, Synonymis, locis. Tomus I.Editio Decima, Reformata. Laurentii Salvii, Stockholm, 823 pp.

LYDEKKER, R. 1885. Indian Tertiary and Post-Tertiary Vertebrata. Siwalik and Narmada Chelonia. Memoirs of the Geological Survey of India. Palaeontologica Indica. Series 10, 3:155-208.

Maung, W. And Ko Ko, W. 2002. Turtles and Tortoises of Myanmar. Wildlife Conservation Society (Myanmar Program), Yangon. (5), $94 \mathrm{pp}$

McCAnN, C. 1934. Notes on the pond terrapin (Geoemyda t.trijuga) in Salsette Island. Journal of the Bombay Natural History Society 39:423.

MCDowell,S.B.,JR.1964.Partition of the genus Clemmys and related problems in the taxonomy of the aquatic Testudinidae.Proceedings of the Zoological Society of London 143:239-279.

Mitchell, J.C. AND Rhodin, A.G.J. 1996. Observations on the natural history and exploitation of the turtles of Nepal, with life history notes on Melanochelys trijuga. Chelonian Conservation and Biology 2:66-72.

MuKhERJEe,D.,NixON,A.M.A., AND Bhupathy, S. 2006. Observations on the morphometry of two subspecies of Melanochelys trijuga from the Western Ghats, southwestern India. Turtle and Tortoise Newsletter 9:7-9.

NABHITABHATA,J.,CHAN-ARd, T., AND ChUAYNKERN, Y.2000.Checklist of Amphibians and Reptiles in Thailand. Office of Environmental Ploicy and Planning, Bangkok, $152 \mathrm{pp}$.

NUTAPHAND, W. 1979. The Turtles of Thailand.Siam FarmZoological Gardens, Bangkok, 222 pp.

Oвsт,F.-J.1983. Beiträg zur Kenntnis der landschildkröten-Gattung Manouria Gray, 1852 (Reptilia, Testudines, Testudinidae).Zoologische Abhandlung Staatliches Museum für Tierkunde, Dresden 38(15):247-256.

PAWAR, S.S. AND CHOUdhURY, B.C. 2000. An inventory of chelonians from Mizoram,north-east India: new records and some observations 
on threats. Hamadryad 25:144-158.

Pendharkar, A. And Jenner, T. 1994. Occurrence of the Indian Black Turtle Melanochelys trijuga in Simbalbara Sanctuary, Himachal Pradesh. Journal of the Bombay Natural History Society 91:461-462.

Platt, S.G., Khaing, S.T., Ko Ko, W., and Kalyar. 2001. Distributional notes on the turtles of western Myanmar. Journal of the Bombay Natural History Society 98:117-120.

Pores, D. 2001. Herpetofauna of the Muthurajawela Marsh, Sri Lanka, with notes on natural history. Herpetological Natural History 8(1):27-35.

PRITCHARD, P.C.H. 1988. A survey of neural bone variation among recent chelonian species, with functional interpretations. Acta Zoologica Cracoviensis 31:625-686.

RASHID, S.M.A. AND KHAN, S.M.H. 2000. Trade and conservation status of freshwater turtles and tortoises in Bangladesh. In: van Dijk, P.P., Stuart, B.L., and Rhodin, A.G.J. (Eds.). Asian Turtle Trade: Proceedings of a Workshop on Conservation and Trade in Freshwater Turtles and Tortoises in Asia. Chelonian Research Monographs No. 2, pp. 77-85.

RHODIN, A.G.J. AND CARR, J.L. 2009. A quarter millenium of uses and misuses of the turtle name Testudo scabra: identification of the type specimens of T. scabra Linnaeus 1758 and T. scripta Thunberg in Schoepff 1792 (= Trachemys scripta scripta). Zootaxa 2226:1-18.

Schleich, H.H. AND Kästle, W. 2002. Order Chelonia/Testudines (turtles: terrapins and tortoises). In: Schleich, H.H. and Kästle, W. (Eds.). Amphibians and Reptiles of Nepal. Biology, Systematics, Field Guide. Koeltz Scientific Books, Koenigstein, pp. 501-573.

SCHWEIGGER, A.F. 1812. Prodromus monographiae cheloniorum. Königsberger Archiv für Naturwissenschaft und Mathematik, Königsberg 1:271-358, 406-458.

SHAH, K.B. AND TIWARI,S. 2004. Herpetofauna of Nepal.AConservation Companion. IUCN Nepal, Kathmandu, 237 pp.

Sharath, B.K. and Hegde,S.N.2003. Two new traps for sampling the black pond turtle (Melanochelys trijuga) in the tropical rainforests of the Western Ghats (India). Herpetological Review 34:33-34.

Sharma, G.P. And NAKHASI, U. 1981. Cytotaxonomic relationships of various species of the family Emydidae (Chelonia: Reptilia).
Chromosome Information Service (30):21-22.

SHYAm Sundar, V. 1984. Notes on nesting activities of the black pond turtle, Melanochelys trijuga trijuga. Hamadryad 9(2):8-9.

Sмiтн, M.A. 1931. The Fauna of British India, including Ceylon and Burma. Vol. I. Loricata, Testudines. Taylor and Francis, London, $185 \mathrm{pp}$.

SPinKs, P.Q., ShafFer, H.B., Iverson, J.B. and McCord, W.P. 2004. Phylogenetic hypotheses for the turtle family Geoemydidae. Molecular Phylogenetics and Evolution 32:164-182.

Theobald, W., JR. 1876. Descriptive Catalogue of the Reptiles of British India. Calcutta: Thacher, Spink and Co., 238 pp.

ThIRAKHUPt, K. AND VAN DiJK, P.P. 1994. Species diversity and conservation of turtles in western Thailand. Natural History Bulletin of the Siam Society 42:207-258.

VAN DIJK, P.P. AND THIRAKHUPT, K. 2000. Conservation status, trade, and management of tortoises and freshwater turtles in Thailand. In: van Dijk, P.P., Stuart, B.L., and Rhodin, A.G.J. (Eds.). Asian Turtle Trade: Proceedings of a Workshop on Conservation and Trade in Freshwater Turtles and Tortoises in Asia. Chelonian Research Monographs No. 2, pp. 137-144.

VIJAYA, J. 1982. Breeding data on Melanochelys trijuga trijuga and Melanochelys trijuga coronata. Hamadryad 7(3):16.

Vyas, R. And Patel, B.H. 1990. A survey of freshwater turtles of Gujarat. Journal of the Bombay Natural History Society 87:151-155.

Wermuth, H. and Mertens, R. 1961. Liste der Rezenten Amphibien und Reptilien. Testudines, Crocodylia, Rhynchocephalia. Das Tierreich, Berlin 100:1-174.

\section{Citation Format for this Account:}

DAS, I. AND Bhupathy, S. 2009. Melanochelys trijuga (Schweigger 1812) - Indian black turtle. In: Rhodin, A.G.J., Pritchard, P.C.H., van Dijk, P.P., Saumure, R.A., Buhlmann, K.A., Iverson, J.B., and Mittermeier, R.A. (Eds.). Conservation Biology of Freshwater Turtles and Tortoises: A Compilation Project of the IUCN/SSC Tortoise and Freshwater Turtle Specialist Group. Chelonian Research Monographs No. 5, pp. 038.1-038.9, doi:10.3854/ crm.5.038.trijuga.v1.2009, http://www.iucn-tftsg.org/cbftt/. 